\title{
Teknologiforståelse i skolens praksis
}

\section{Datalogisk design til autentisk problemløsning}

\author{
Elisa Nadire Caeli, Danmarks institut for Pædagogik og Uddannelse (DPU), Aarhus Universitet samt \\ Institut for Læreruddannelse, Københavns Professionshøjskole \\ Martin Dybdal, Datalogisk Institut, Københavns Universitet
}

\begin{abstract}
Denne artikel er et fagdidaktisk bidrag til det fagområde, der i grundskolekontekst kaldes teknologiforståelse. Teknologiforståelse forstås i denne kontekst som en faglighed, der indebærer udvikling af kompetencer inden for datalogisk tænkning, designtænkning og kritisk tænkning om brug af datalogi i samfundet.

I artiklen formidles og analyseres resultaterne af et eksperiment, gennemført i foråret 2019 i en 8.

klasse. Formålet var at undersøge undervisning i datalogisk tænkning og designtænkning i dansk almendannede grundskole gennem udvikling af et datalogisk design til autentisk problemløsning og derved udlede fagdidaktiske henholdsvis muligheder og udfordringer i en sådan undervisning. Eksperimentet tog udgangspunkt i to primære hypoteser: en forventet modstand fra eleverne mod at ville lave om på deres design efter brugerfeedback, samt at eleverne ville have et snævert syn på datalogi som det samme som programmering. Disse hypoteser blev delvist bekræftet, men også andre henholdsvis muligheder og udfordringer blev identificeret, herunder ændrede opfattelser af og nye muligheder for succes med datalogi, succes med kreative afbræk og vekslende arbejdsmåder, en positiv betydning af autenticitet for elevernes forståelse og ønske om flere frihedsgrader, end de fik i dette projekt.
\end{abstract}

\section{Engelsk abstract}

This article is a didactic contribution to the subject area known as "technology comprehension" in Danish K-9 schools. In this context, technology comprehension is regarded as a discipline that involves developing competences in the fields of computational thinking, design thinking, and critical thinking regarding the use of computer science in society.

The article communicates the results of an experiment conducted in a Danish eighth-grade class. The purpose was to examine a way of teaching computational thinking and design thinking by developing a computational design to solve an authentic problem, thereby identifying didactic opportunities and challenges.

The experiment was based on two primary hypotheses: We expected the students would dislike the idea of changing their designs after user feedback, and we thought they would have a narrow view of computer science, regarding it as the equivalent of programming. These hypotheses were partially confirmed. However, other opportunities and challenges were also identified, including changed conceptions of computer science and new opportunities for success within the field, success with creative breaks and varied ways of working, the positive importance of authenticity with regard to the students' understanding, and the wish for a greater degree of freedom than they were granted in this project. 


\section{Introduktion}

Denne artikel formidler resultaterne af et dansk forskningsprojekt, gennemført i en 8. klasse på en folkeskole i marts 2019. Vi havde designet et tredages forløb med henblik på, at eleverne udviklede en digital løsning på et virkeligt problem. Formålet var at undersøge en undervisningspraksis, hvor eleverne udviklede forståelse for samt kompetencer inden for datalogisk tænkning, herunder design og programmering med brug af data som midler til at udvikle en løsning på et autentisk problem for mennesker, fremfor at sådanne færdigheder blev mål i sig selv løsrevet fra virkelige praksisser. Specifikt ønskede vi at undersøge fagdidaktiske henholdsvis muligheder og udfordringer i udvikling og gennemførelse af et sådant forløb.

Projektet er gennemført i en tid, hvor datalogi som faglighed i grundskolen har fået stor international opmærksomhed. Verden over pågår der forsøg med at indføre datalogisk tænkning (eng. computational thinking), enten som selvstændigt fag eller som del af andre fagligheder i grundskolen. I Danmark har det blandt andet betydet, at Undervisningsministeriet har søsat forsøgsfaget og -fagligheden teknologiforståelse fra marts 2019, hvor elever på 46 skoler undervises i dette fagområde med det overordnede formål at "udvikle faglige kompetencer og opnå færdigheder og viden, således at de konstruktivt og kritisk kan deltage i udvikling af digitale artefakter og forstå deres betydning" (EMU, 2019).

Metodisk var nærværende projekt udformet som et designeksperiment inden for det fagområde, der i grundskolekontekst kaldes teknologiforståelse med udgangspunkt i en problemstilling inden for det naturfaglige område. Eksperimentet blev planlagt af os begge og gennemført med den ene af os som underviser og den anden som observatør. Det er planlagt og gennemført uafhængigt af ministeriets forsøg, hvilket betyder, at vi i vores undervisningsdesign ikke har taget udgangspunkt i forsøgsfagets Fælles Mål for forsøgsfaget teknologiforståelse, men at vi med udgangspunkt i forskning på området og teoretiske analyser har udviklet egne mål og fagdidaktiske overvejelser. Vores udgangspunkt er et syn på teknologiforståelse som en faglighed, der indebærer udvikling af kompetencer inden for datalogisk tænkning, designtænkning og kritisk tænkning om brug af datalogi i samfundet (Caeli \& Bundsgaard, 2020). I denne kontekst undersøger vi specifikt kompetencer inden for datalogisk tænkning og designtænkning gennem ottendeklasseelevers udvikling af et datalogisk design.

\section{Artiklens opbygning og forskningsbidrag}

I artiklen præsenterer vi først den samfunds- og uddannelsesmæssige kontekst, eksperimentet lægger sig ind i, samt dets teoretiske og metodiske grundlag. Dernæst introducerer vi vores undervisningsdesign og beskriver samt analyserer praksis gennem konkrete nedslag. Vi diskuterer derefter vores resultater, herunder hvad der lykkedes, og hvad der ikke lykkedes fra både vores samt elevernes perspektiver, og vi italesætter, hvilke muligheder og udfordringer vi ser i implementeringen af en sådan teknologiforståelse i praksis. Afslutningsvist samler vi op med en konklusion.

Eksperimentet er ment som et konkret og autentisk eksempel på, hvordan lærere kan undervise i de dele af teknologiforståelse, vi benævner datalogisk tænkning og designtænkning og indeholder derfor en detaljeret beskrivelse af praksis. I artiklen identificeres tillige andre potentielle muligheder og udfordringer, vi identificerede gennem eksperimentet, og nødvendige kulturforandringer diskuteres. 


\section{Datalogi og projektorientering}

Nærværende eksperiment bygger på forhenværende professor i datalogi Peter Naurs syn på datalogi som et samspil mellem mennesker og computere, og at faget til stadighed må bevare en orientering mod anvendelse.

Naur påpegede, at udgangspunktet for et projekt er en ufuldstændig beskrivelse, hvor mange vidt forskellige løsninger kan være fuldt acceptable (Naur, 1970). Samtidig slog han fast, at programmering blot er et værktøj i en sådan proces, hvilket han blandt andet illustrerede med en model over forholdet mellem mennesker, problemer og værktøjer (Figur 1).

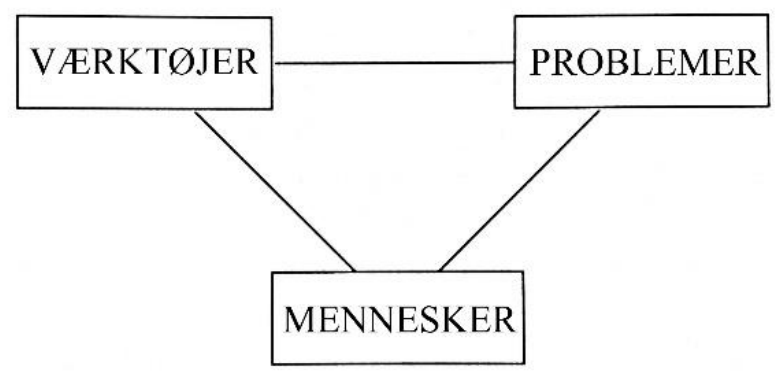

Figur 1. Forholdet mellem problemer, værktøjer og mennesker (Naur, 1965)

Naur forklarede, at mennesker kun kan forstå problemer på baggrund af værktøjer, og at værktøjer, der er designet til at løse problemer, ingen forstår, er meningsløst. Videre sagde han, at problemer kun eksisterer som sådanne i kraft af menneskets bevidsthed og kun relativt til forståede værktøjer, og at værktøjer kun eksisterer som værktøjer, hvis nogle mennesker tænker på dem som passende ting at løse problemer med (Naur, 1965).

Modellen er fortolket til fagdidaktisk brug i en nutidig kontekst af den ene af denne artikels forfattere (Caeli, forthcoming). Her eksemplificeres det, hvorledes læreren kan anvende den i planlægning, gennemførelse og evaluering af undervisning til at skabe opmærksomhed på alle tre perspektiver og deres relation ved at stille sig selv og eleverne nedenstående spørgsmål.

\footnotetext{
"Hvordan er relationen mellem problemer og mennesker? Løser eleverne bevidst et problem, der har relevans for mennesker? Her kan læreren blive opmærksom på, om de arbejder med autentiske problemer, eller om der er risiko for digitalisering, "fordi vi kan".

Hvordan er relationen mellem mennesker og værktøjer? Forstår og tænker eleverne på værktøjerne som passende ting at løse problemer med? Her kan læreren blive opmærksom på, om eleverne har forudsætningerne for at løse problemer, og om de forstår værktøjer til åben problemløsning, eller om der er risiko for snævre funktionelle brugerfærdigheder i brug af værktøjer.
}

Hvordan er relationen mellem værktøjer og problemer? Bliver værktøjerne brugt til at løse problemer, som eleverne forstår som problemer? Her kan læreren blive opmærksom på, om værktøjerne bruges til løsning af problemer, eller om der er tendens til, at brugen bliver målet i sig selv" (Caeli, forthcoming).

Ifølge Naur bør problemløsning altså foregå som en proces med en bevidst relation mellem de tre faktorer. Dette mener vi er væsentligt i en undervisningskontekst, så man eksempelvis ikke kommer til at fokusere ukritisk på at lære et specifikt værktøj uden en reel problemstilling eller uden forståelse for, 
hvad værktøjet kan anvendes til i virkeligheden. I nærværende eksperiment skulle eleverne arbejde kreativt med problemløsning gennem designtænkning og datalogisk tænkning.

\section{Designtænkning, datalogisk tænkning og datalogisk design}

I nyere tid er begrebet designtænkning blevet populariseret $\mathrm{i}$ bred form som en metode til problemløsning, men begrebet har en lang historie. Professor John Edward Arnold anses som en af de første, der anvendte begrebet, da han i 1959 i bogen "Creative Engineering" beskrev det som en særlig tilgang til kreativ problemløsning. Designforskeren Nigel Cross forklarer, at designtænkning indebærer processer som analyse af kontekst, generere og afgrænse problemer, generere ideer, tænke kreativt, lave udkast, skitser, modeller og prototyper, afprøve sit design samt evaluere (Cross, 2011).

I vores projekt kobler vi datalogi og design. En sådan kobling diskuterer Denning i en artikel (2017), hvor han præsenterer begrebet datalogisk design (computational design), som vi opfatter som velegnet i dette eksperiment. Datalogisk design lægger sig i krydsfeltet mellem datalogisk tænkning og det, som er blevet benævnt datalogisk handling (computational doing). Ifølge Denning refererer datalogisk tænkning til en proces, hvor man finder en datalogisk løsning på et problem eller en sag ${ }_{1}$, og datalogisk handling refererer til selve brugen af datalogi og datalogiske værktøjer til løsning af problemer. Design refererer i stedet til skabelse af nye datalogiske værktøjer og metoder, som løser problemer (eller sager) for mennesker, og - ikke mindst - som mennesker tager til sig. Om relationen siger han:

"Clearly, designers are a subset of thinkers because you need to be a computational thinker to design computational tools; and not every thinker is a designer. Also, designers are tool users, but not all tool users are designers or thinkers."

Nedenstående model (Figur 2) illustrerer denne relation.

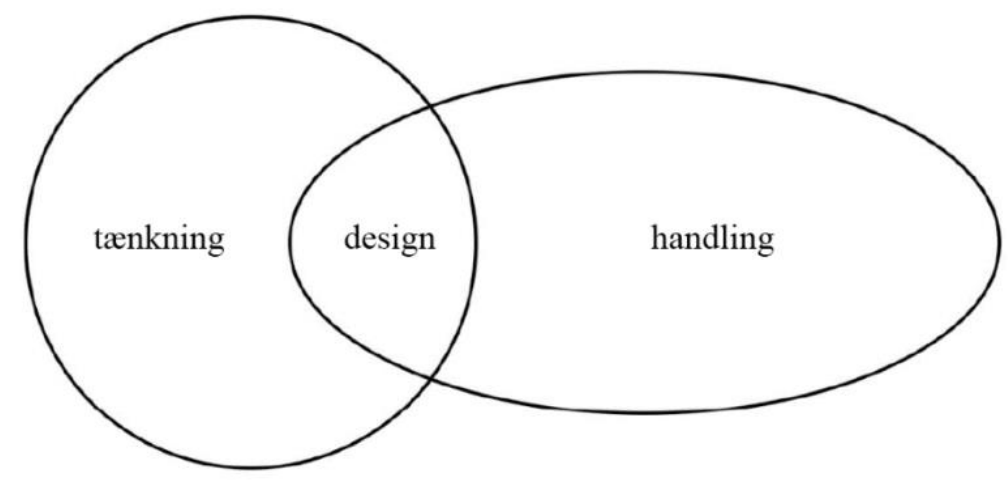

Figur 2. Forholdet mellem datalogisk tænkning, datalogisk handling og datalogisk design (Denning, 2017 - vores oversættelse).

1 Denning bruger udtrykket concerns (her oversat til sager) i stedet for problems, fordi vi ofte bruger datalogi til at løse sager, der ikke ses som problemer. Et eksempel på dette kan være udvikling af spil, der næppe kan ses som løsning på et problem. I denne artikel anvender vi dog det danske problem, da problemløsning er etableret som begreb i uddannelse, og eftersom der i vores eksperiment netop var tale om løsning af et problem. 
Denne kobling var en grundpille i eksperimentet, hvilket kommer til udtryk i et senere afsnit om eksperimentet i praksis.

\section{Metodisk tilgang og didaktiske overvejelser}

\section{Forskningsspørgsmål og hypoteser}

Formålet med eksperimentet var at undersøge undervisning i datalogisk tænkning og designtænkning i dansk almendannede grundskole gennem udvikling af et datalogisk design til autentisk problemløsning og derved udlede fagdidaktiske henholdsvis muligheder og udfordringer i en sådan undervisning.

Vi ønskede, at eleverne skulle designe og programmere et produkt, der kunne løse et autentisk problem i verden. Hensigten var og er, at vores formidling af eksperimentet og analyserne af praksis derved kan bidrage til en fagdidaktik for teknologiforståelse, som andre kan bygge videre på eller lade sig inspirere af. I den henseende har vi arbejdet ud fra følgende overordnede forskningsspørgsmål:

Hvilke fagdidaktiske og kulturelle henholdsvis muligheder og udfordringer kan der være ved undervisning i datalogisk tænkning og designtænkning i dansk grundskolekontekst?

Vi havde en hypotese om, at en iterativ tilgang til datalogi og design i skolen kunne blive problematisk, og at eleverne var mere vant til skolearbejde som en lineær proces fra A til B. Dette var blandt andet foranlediget af tidligere forskning på området, der har vist, at det for lærere kan være udfordrende at undervise i sådanne fleksible processer (Smith m.fl., 2016). Mere specifikt var vores hypotese, at det kunne være svært at få eleverne til at ville lave om på deres produkt efter brugerfeedback, når de først mente, at deres design var færdigt. Vi var dog enige om, at det var vigtigt, at eleverne fik forståelse for, hvordan en datalogisk designer i virkeligheden arbejder. Derfor skulle de også have erfaring med iterationer.

En anden hypotese var, at eleverne ville se snævert på datalogi som programmering i betydningen "skrive i kode". Det var derfor et opmærksomhedspunkt for os, at eleverne opdagede, at en datalog laver meget andet end at taste koder på et tastatur. Denne hypotese udspringer blandt andet af den måde, vi i samfundet anvender begreberne på. Vi sporer en tendens til, at begreberne programmering og kodning ofte sidestilles - men i vores forståelse omfatter programmering alle trin i en systemudviklingsproces, herunder også design af systemet, og ikke blot den specifikke handling at indtaste koder. En begrænset forståelse af programmering kan blandt andet føre til, at eleverne ikke anser designaspekter for væsentlige, og at korrekt kode således i sig selv bliver målet.

\section{Metodisk tilgang}

Projektet blev udformet som et designeksperiment, inspireret af designbaseret forskning (vores oversættelse af design-based research). Formålet med designbaseret forskning er blandt andet at udforske komplekse undervisningspraksisser på en måde, der er værdifuld for andre - dvs. på en måde, hvor eksperimentets konstruktioner kan overføres fra den konkrete kontekst til en anden. Det er en formativ, procesorienteret evalueringsmetode, hvorigennem man undersøger et fænomen for at forstå både tilsigtede og utilsigtede konsekvenser. Ofte udføres designbaseret forskning således som iterationer i form af gentagne forbedrede interventioner for på den måde at generere nye teorier (Barab \& Squire, 2004). I vores eksperiment testede vi de ovenfor præsenterede teorier samt analyserede og diskuterede forbedringer til vores design på baggrund af vores realiserede erfaringer for herigennem at bidrage til generering af fagdidaktisk teori på dette nye område. Eksperimentet er ikke gennemført med 
iterationer, men beskrivelser og diskussioner lægger op til, at andre kan gennemføre og videreudvikle på forløbet.

\section{Didaktisk ståsted og dannelsessyn}

Vores eksperiment tog afsæt i den tyske dannelsesteoretiker og didaktiker Wolfgang Klafkis kritiskkonstruktive forståelse af, at dannelse af mennesket også er et samfundsspørgsmål. Det betyder blandt andet, at: "dannelsesteori og dannelsespraksis har mulighed for og får til opgave, ikke kun at reagere på forhold og udviklinger i samfundet, men derimod at vurdere og være med til at forme disse ud fra et pædagogisk ansvar for nutidige og fremtidige leve- og udviklingsmuligheder ...” (Klafki, 2001). I den henseende gør han blandt andet op med den klassiske kanontanke om en almendannende kerne bestående af en fastlagt række af kulturelementer. I stedet præsenterer han en ny kerne på grundlag af en kritisk historisk-samfundsmæssig-politisk og samtidig pædagogisk bevidsthed, hvor undervisningen koncentrerer sig om "tidstypiske nøgleproblemer i samtiden og den formodede fremtid".

I vores eksperiment tog vi udgangspunkt i miljøspørgsmålet som et af de tidstypiske nøgleproblemer, Klafki nævner, herunder i særlig grad den del, han beskriver som:

"udvikling af den indsigt, at det er nødvendigt at udvikle ressource- og energibesparende teknologi samt miljøvenlige produkter og produktionsformer, ligesom det er nødvendigt dels at begrænse vores konsum, dels at gøre det miljøvenligt".

Klafki pointerer endvidere, at almendidaktikken ikke kan se bort fra de område- og fagdidaktiske konkretiseringers dimensioner:

"Der kan kun findes svar på de almendidaktisk formulerede spørgsmål ved at tage områdeog fagdidaktiske erkendelser til hjælp" (Klafki, 2001).

I vores eksperiment rettede vi overvejende fokus mod teknologiforståelse som faglighed, som også er fokus for denne artikel, hvorfor det naturfaglige område ikke berøres i nævneværdig grad i artiklen. I den forbindelse gjorde vi brug af forskellige ekspertiser som henholdsvis lærerspecialist og indholdsspecialist inden for datalogi til at koble faglig og almendidaktisk viden til en fagdidaktisk.

\section{Design og gennemførelse af eksperimentet}

Eksperimentet blev gennemført i tre hele skoledage i en 8. klasse i marts 2019. Skolen lå i Københavns vestegn og den specifikke klasse bestod af 20 elever, heraf 10 drenge og 10 piger, hvor 95 procent havde anden etnisk baggrund end dansk (19 elever), og 80 procent var flersprogede (16 elever).

\footnotetext{
2 Elisa Nadire Caeli er tidligere uddannet lærer, cand.mag. i læring og forandringsprocesser og arbejder nu som ph.d.-stipendiat på et forskningsprojekt omhandlende elevers udvikling af datalogisk tænkning og teknologiforståelse i grundskolen. Martin Dybdal er tidligere uddannet cand.scient. samt ph.d. i datalogi og arbejder nu som specialkonsulent, hvor han forsker i og arbejder med datalogididaktik og formidling fra grundskole- til universitetsniveau.
} 
Forud for undervisningen udarbejdede vi den overordnede undervisningsplan (bilag 1), undervisningsslides samt arbejdsark ${ }_{3}$ og sørgede for de nødvendige materialer og ressourcer til brug i selve undervisningen ${ }_{4}$. Undervisningsplanen er i denne udgave tilpasset efterfølgende, så læseren kan få indblik i, hvad der faktisk foregik i undervisningen og eventuelt lade sig inspirere heraf. Angivelsen af minuttal er vejledende.

Konkret designede og gennemførte vi eksperimentet i samarbejde, men ved gennemførslen havde vi forskellige roller. Martin Dybdal underviste, mens Elisa Nadire Caeli observerede undervisningen, herunder skrev feltnoter samt gik i dialog med eleverne. Elisa Nadire Caeli underviste således ikke, men fungerede ud over observatør løbende som sparringspartner i forhold til didaktiske og pædagogiske tiltag og ændringer undervejs. Ud over Elisa Nadire Caeli og Martin Dybdal deltog Maja Hvidtfeldt Håkansson, der er datalogistuderende og uddannet arkitekt, som assisterende underviser, da vi anså det for nødvendigt med to undervisere $\mathrm{i}$ en sådan form for projektorienteret undervisning $\mathrm{i}$ et nyt fagområde.

\section{Dataindsamling og -analyse}

Designeksperimentet blev således udarbejdet af os i et samarbejde som henholdsvis indholdsspecialist og lærerspecialist med udgangspunkt i de beskrevne fagfaglige og fagdidaktiske teorier. Dette udmøntede sig i en undervisningsplan, hvor eleverne skulle udvikle et datalogisk design med udgangspunkt i et tidstypisk nøgleproblem inden for det naturfaglige område. Dataindsamlingen foregik gennem afprøvning af eksperimentet i praksis, hvor vi observerede undervisningen, skrev feltnoter og optog video. På den baggrund har vi udledt en række lærer- og elevcitater, som vi har analyseret i artiklens sidste del - særligt fra vores evaluering med eleverne. Evalueringen foregik delvist ustruktureret, da vi ikke ønskede at styre samtalen for meget. Vi ønskede elevernes umiddelbare indspark. Det empiriske materiale, der ligger til grund for denne artikel, er således kvalitativt, hvor vi med udgangspunkt i elevcitater og egen evaluering analyserer og diskuterer processen.

Hvordan eksperimentet og evalueringen specifikt så ud, præsenterer og diskuterer vi i det følgende. Hensigten med at dele den specifikke undervisningsplan og undervisningsslides samt detaljeret at beskrive eksperimentet i praksis er, at andre kan afprøve og videreudvikle forløbet eller lade sig inspirere heraf.

\section{Eksperimentet i praksis}

Eksperimentet var tilrettelagt delvist lukket for at modellere problemløsning gennem datalogisk design som et første skridt i udviklingen mod at blive mere selvstændige datalogiske designere. Vi havde som nævnt en hypotese om, at eleverne ikke var vant til at arbejde på denne måde. Det betød også, at vi på forhånd havde udvalgt den problemstilling, eleverne skulle arbejde med, samt dele af deres løsning: De skulle udvikle en prototype (et fysisk samt programmeret design) med LED-strips, der ville kunne hjælpe os mennesker med at bruge mindre $\mathrm{CO}_{2}$ gennem vores elforbrug. Fra dataudbyderen electricitymap.org skulle de hente data ned om Danmarks realtids- $\mathrm{CO}_{2}$-udledning og programmere

3 Undervisningsslides og arbejdsark kan ses og downloades på

https://silo1.sciencedata.dk/shared/designeksperiment, såfremt man ønsker at afprøve eksperimentet eller dele af det med sine egne elever.

4 Se beskrivelsen af praksis for mere information om materialer og ressourcer. 
LED’erne til at "give besked om" (dvs. lyse på bestemte måder), når $\mathrm{CO}_{2}$-udledningen i Danmark er henholdsvis lav og høj. Dermed skulle deres design kunne vise, hvornår ens elforbrug udleder mindst $\mathrm{CO}_{2}$ (for eksempel fordi vi bruger vindenergi), og hvornår det derfor er mindst miljøbelastende at forbruge elektricitet. LED'erne skulle bygges ind i en fysisk prototype. Eleverne skulle selv finde på ideer til deres fysiske design, herunder hvor det skulle placeres, og om det skulle integreres i et eksisterende produkt eller tænkes som et nyt produkt. De skulle også finde på og programmere, hvordan LED'erne skulle vise, hvorvidt det var en god idé at anvende elektricitet eller ej. Hvis man for eksempel kan se, at $\mathrm{CO}_{2}$-udledningen er høj, kan man blive opmærksom på, at det vil være en god idé at vente med at starte opvaskemaskinen eller oplade mobiltelefonen, til den bliver lavere, da det vil betyde, at den energi, man bruger, er grønnere.

Almendidaktisk tog vi afsæt i miljøspørgsmålet som tidstypisk nøgleproblem, med henblik på at eleverne udviklede indsigt om nødvendigheden af at udvikle ressource- og energibesparende teknologi samt miljøvenlige produkter. Fagdidaktisk anvendte vi fagområderne datalogi og design som tværgående hjælpefag. Som fælles ramme til at skabe overblik og hjælpe med at anskueliggøre en kaotisk og uforudsigelig designproces, anvendte vi en designmodel (Figur 3) til at illustrere og samtale med eleverne om, hvor vi var på vej hen, hvor i processen vi var, og hvad næste skridt på vejen var.

I det følgende beskriver vi praksis fra hver af de tre dage med konkrete nedslag. I beskrivelsen har vi valgt hovedsageligt at fokusere på undervisningens faglige indhold og fagdidaktiske valg. Dvs. at vi ikke går dybere ind i kontekstuelle og kulturelle faktorer, såsom elever, der gik ind og ud af klassen, "larmede", brugte mobiltelefon eller spiste snacks i timerne. Om end disse faktorer er væsentlige og skal indtænkes, når man underviser på lignende måder i egen klasse, hvor man kender eleverne og kan arbejde mere fokuseret med kulturen i klassen, er de ikke hovedfokus i denne artikel - både af hensyn til omfang, og fordi de ikke har nævneværdig betydning i forhold til artiklens generelle udsagn. Vi vil dog kort diskutere nogle af disse udfordringer i vores egen analyse af eksperimentet sidst i artiklen.

\section{Dag 1: Forståelse for problemet, forståelse for data og afgrænsning af projekt}

Som det fremgår af vores undervisningsslides6, startede vi eksperimentet med at introducere Naurs model for relationen mennesker, problemer og værktøjer (Figur 1). Ved hjælp af modellen konkretiserede vi, at eleverne skulle designe løsninger til mennesker på et aktuelt problem i verden, og at de for at løse problemet, skulle bruge nogle værktøjer. Dette ledte os frem til designmodellen (Figur 3), som vi introducerede som det næste, for at eleverne kunne få en idé om, hvad de næste tre dage ville komme til at gå ud på, herunder hvor vi skulle starte, og hvor vi planlagde at skulle slutte. Modellen er inspireret af "Værktøjskassen" (Katapult/TEACH, 2013) og en designmodel fra School of Design, Stanford University7, men tilpasset den specifikke klimaproblematik, eleverne skulle arbejde med.

\footnotetext{
5 Denne tilgang er inspireret af John Hattie og Helen Timperleys model for feedback, der blandt andet har til hensigt at involvere eleverne i deres læring ved at gøre processen synlig (Hattie \& Timperley, 2013).

6 Se eventuelt undervisningsslides, hvor konkrete aktiviteter, spørgsmål, modeller osv. fremgår, som supplement til vores beskrivelse af praksis: https://silo1.sciencedata.dk/shared/designeksperiment.

7 https://dschool.stanford.edu/
} 


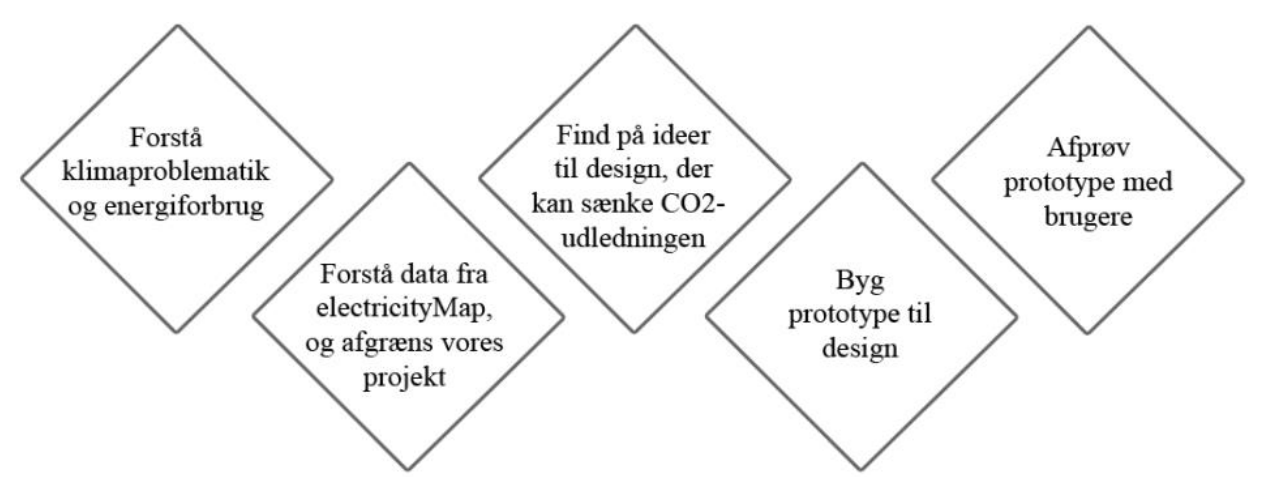

Figur 3. Vores designmodel, udfyldt med eksperimentets specifikke indholdsområde "klimaproblemet og energiforbrug".

Første fase i modellen omhandlede forståelse for klimaproblematikken og energiforbrug. I modsætning til klassens lærere kendte vi ikke eleverne, og derfor kendte vi heller ikke deres forhåndsforståelse på området. Dagen før eksperimentet startede, fik vi dog at vide, at eleverne netop var gået i gang med naturfaglige projektuger om bæredygtig energiforsyning, og denne forforståelse var naturligvis gavnlig for eksperimentet.

Vi startede dag 1 med en åben dialog om klimaforandringerne, hvorefter vi viste eleverne en kort video om drivhuseffekten og om klimaforandringernes årsager og konsekvenser. Dernæst diskuterede vi, hvad vi mennesker kan gøre for at modvirke klimaforandringer, vi snakkede om strømforbrug og strømproduktion, og vi introducerede til electricitymap.org. For eksempel snakkede vi om, hvorfor Frankrig lige nu var meget "grønnere" end Estland, og hvad der kunne forårsage, at Bornholm var grønnere end eksempelvis Sjælland. Denne dialog koblede vi til afgrænsningen af vores problemløsningsprojekt, der skulle omhandle mindre $\mathrm{CO}_{2}$-udledning, specifikt gennem brug af data fra electricitymap.org, som eleverne skulle koble til et eget datalogisk design, der skulle inkludere programmering af LED'er.

Her anskueliggjorde vi igen med udgangspunkt i Naurs model (Figur 1), hvorfor en række kendte værktøjer, designet til at løse et problem for mennesker, mon er designet, som de er. Hvorfor er ringklokken for eksempel ikke designet som en lampe, som lyser, når der står nogen uden for døren? Hvorfor er farverne i et trafiklys rødt, gult og grønt? Osv.

Dernæst introducerede vi elektronikken samt programmering af LED'er. I dette eksperiment havde vi medbragt egne computere, der indeholdt den software, vi ønskede at anvende, og som vi på forhånd havde tjekket fungerede. Vi havde desuden medbragt ESP32-microcontrollere, LED-strips og et 4G wifihotspot for at minimere risikoen for tekniske eller infrastrukturelle problemer med systemer udefra, vi ikke kendte til.

Eleverne skulle eksperimentet igennem arbejde i par med én computer til deling. Som nævnt var dette forløb delvist lukket i den forstand, at vi modellerede store dele af forløbet for eleverne på en måde, hvor de fik forståelse for, hvordan datalogiske designere arbejder. Det var således ikke vores hensigt, at eleverne i disse tre dage skulle udvikle sig til programmører - hvilket også ville have været ganske urealistisk. De skulle netop opleve programmering som et værktøj til løsning af et virkeligt problem i 
verden. Derfor fik de også meget af koden foræret på arbejdsark. På det første arbejdsark \#1 skulle de eksempelvis starte med at åbne programmet Mus og indtaste kode som nedenfor (Figur 4).

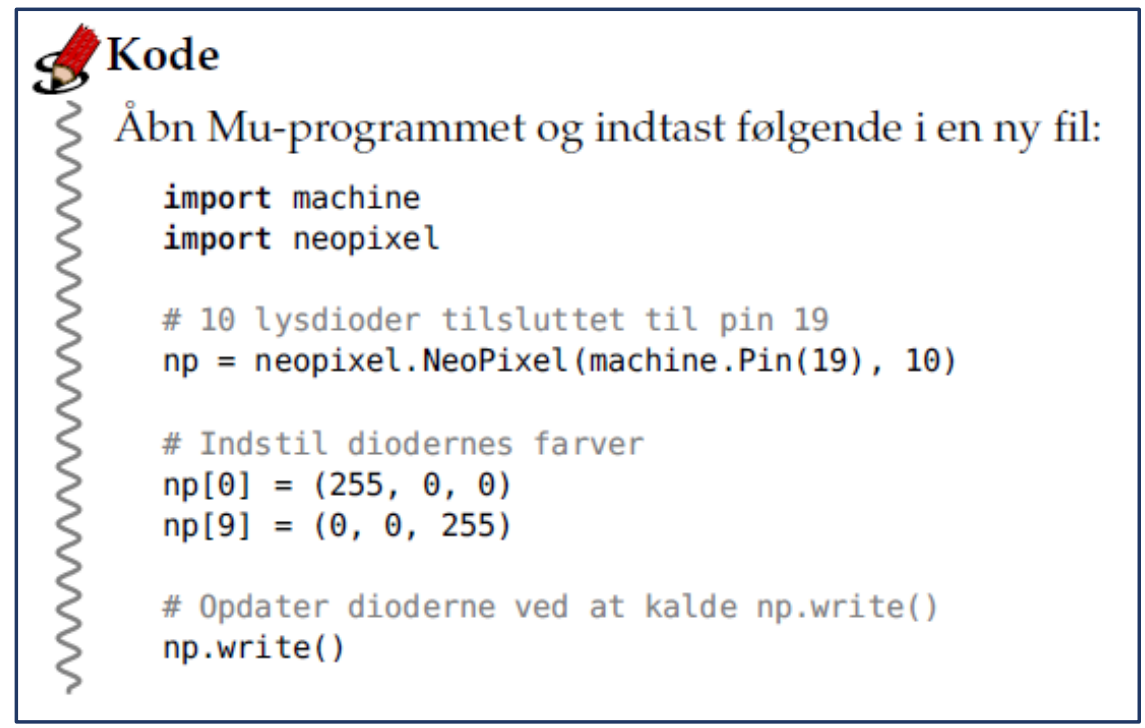

Figur 4. Eksempel på kode fra arbejdsark.

Derefter skulle de afprøve, om koden virkede efter hensigten: Den første diode [o] burde her lyse rødt, og den tiende [9] burde lyse blåt.

Efterfølgende arbejdede eleverne selv med udvidelse af programmet, så hver anden diode blev rød og hver anden blå, og til sidst eksperimenterede de selv med farverne ved hjælp af farvekoder fra arbejdsarket. Dette afstedkom hurtigt en række spørgsmål, såsom hvorfor der kun er to, der lyser, og hvordan de kunne tænde alle. Altså var de motiverede af, at de selv kunne påvirke, hvordan deres LED’er lyste.

Efter den første eksperimenteren ønskede vi, at eleverne skulle lære, hvordan man kan samarbejde om at programmere gennem metoden parprogrammering ${ }_{9}$ med udgangspunkt $\mathrm{i}$, at man har fundet $u$ d af, at man laver meget bedre programmer, hvis man sidder to ved en computer. Reglerne for parprogrammering introducerede vi som følgende:

8 En simpel Python kodeeditor for begynderprogrammører: https://codewith.mu/

${ }_{9}$ Se eventuelt Tabel et al., 2017 for uddybende omkring parprogrammering i undervisningskontekst. 
* Den ene er chauffør (driver), den anden er navigatør (navigator).

* Chaufføren har hænderne på rattet (tastaturet) og øjnene på vejen (skærmen).

* Navigatøren har "kortet” med fokus på destinationen, og hvordan man kommer derhen.

* Navigatøren må ikke røre tastaturet eller musen, og chaufføren må ikke ignorere navigatøren.

* Man må ikke kommandere.

* Man skal samtale pænt.

* Man skal forsøge at holde en samtale i gang og hele tiden snakke om det, man laver, så man får sat ord på de ting, man lærer.

En af ideerne var nemlig også, fortalte vi eleverne, at de skulle få et ordforråd og blive bedre til at tale om programmerne.

Da eleverne havde eksperimenteret med farver og pænere koder, skulle de ved hjælp af næste arbejdsark \#2 lære at forbinde deres microcontroller til wifi samt hente $\mathrm{CO}_{2}$-data fra electricitymap.org, som de skulle anvende i deres design til at fă LED'erne til at visualisere $\mathrm{CO}_{2}$-udledningen i Danmark i realtid. Hvor de i starten var motiverede af at kunne få LED'erne til at lyse, iagttagede vi, at var ved at miste koncentrationen og motivationen til at programmere. Vi forklarede dem, at de dagen efter skulle i gang med en kreativ proces, hvor de også skulle tegne og bygge med pap. Men for at få LED'erne til at vise $\mathrm{CO}_{2}$-udledningen måtte de første lære, hvordan de kunne bruge de data fra electricitymap.org, de havde hentet. Dette arbejdede vi med resten af dagen.

\section{Dag 2: Ideer til design og bygning af prototype}

Dag 2 startede med en opsamling på dagen før, hvilket dels fungerede som formativ evaluering for os i forhold til elevernes forståelsesniveau, dels som en påmindelse til eleverne om, hvor i processen vi var. Gennem løbende statusser og dialoger blev det muligt for os at holde øje med tegn på deres forståelse, hvilket vi anså for vigtigt i en delvist åben problemløsningsproces, som vores eksperiment var. Der var ikke rigtige og forkerte svar, som vi blot kunne "kontrollere" og sætte flueben ved - eller det modsatte.

Dernæst gik vi i gang med næste fase, som omhandlede ideer til design. Hvor dag 1 således - foruden forståelse for den naturfaglige problematik - centrerede sig om datalogiske kompetencer, centrerede dag 2 sig i højere grad om designkompetencer og derefter om koblingen mellem de to.

Vi startede med en brainstorm over gode og dårlige design, herunder hvad man skal tænke på, når man interagere med brugere, og hvad de selv syntes, var vigtigt i et design. Alle ideer blev skrevet op på tavlen. Af gode ting nævnte de, at et godt design skulle: have den rigtige størrelse til kroppen, passe til vores vaner, være langtidsholdbar, være nyt og kreativt, være simpelt, hjælpe mennesker, se flot ud, føles rart, virke, løse problemet, være af god kvalitet samt være let at finde ud af. Et dårligt design beskrev de som et, der: er af dårlig kvalitet, er svært at forstå, nemt går i stykker, er for lille eller stor, er svær at bruge, ikke løser problemet samt er irriterende. Dernæst så vi en kort video, hvor en række kendte danskere fortalte, hvad de synes, et godt design er. Vi havde bevidst valgt, at eleverne selv skulle aktivere deres forforståelse med ideer, før de fik udefrakommende argumenter og ideer.

Vi forsøgte dernæst at få eleverne til at rangordne ideerne om, hvad der kendetegner et godt design efter, hvor vigtige de var for eleverne. For eksempel spurgte vi dem, hvad der er vigtigst: at et design ser flot ud, eller at det passer til vores krop og vaner? "At det ser flot ud", sagde en elev. "Det er vigtigere, at det passer", sagde en anden, hvortil den første svarede: ”Ja, jeg er enig. Jeg har changed my mind.” Sådanne diskussionspunkter havde vi planlagt, da vi fandt dem hensigtsmæssige til udvikling af 
samarbejdskompetencer og indsigt i andre brugeres perspektiver, der i vores optik og med reference til vores designmodel er påkrævet som kompetent datalogisk designer.

Dernæst viste vi eleverne nogle prototyper, der kunne konkretisere det, de om lidt selv skulle i gang med, samt tjene som udgangspunkter for en dialog om, hvorvidt disse prototyper var godt designede - med baggrund i de kriterier, de netop selv havde diskuteret. Dialogen gav også anledning til samtaler om, hvad der måske ikke var så vigtigt i en prototype. For eksempel var deres kriterier "god kvalitet" og "ser flot ud" måske ikke så vigtige i en prototype, talte vi om.

Derefter gik eleverne i gang med at planlægge deres design. De skulle først engang snakke sammen om, hvad deres design skulle kunne, og hvor det skulle placeres, samt lave en skitse på papir over, hvordan det skulle se ud. Herefter startede fasen Byg prototype til design. Vi havde på forhånd bedt eleverne indsamle og medbringe byggematerialer som pap og flamingo, ligesom vi selv havde medbragt materialer. Derudover var der sakse, hobbyknive, tusser og limpistoler til rådighed. Elektronikken skulle som en væsentlig del af designet indtænkes i denne proces, og således vekslede eleverne mellem at bygge med pap, placere LED-strippen samt programmere, hvordan LED'erne skulle "opføre sig”. Figur 5 giver en fornemmelse for processen med eksempler på papirskitse, prototyper og kode.
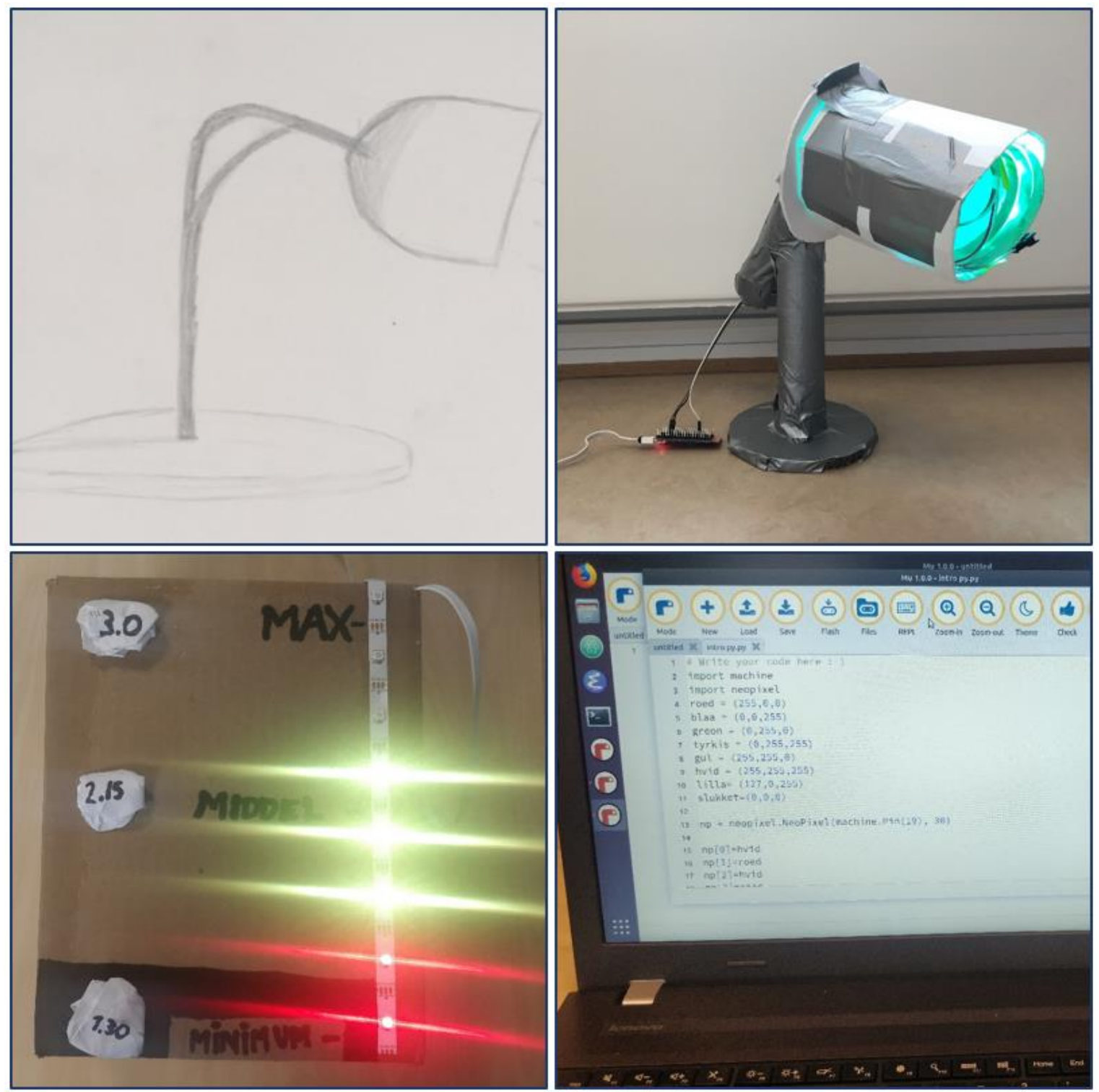

Figur 5. Eksempler på gruppers papirskitser, koder og prototyper. 


\section{Dag 3: Afprøvning, brugerfeedback, ny prototype samt præsentation}

Efter en opsamling på dag 2, rammesatte vi næste fase, Afprøvning med brugere, som her var planlagt som peer-feedback. To grupper skulle sammen vise hinanden, hvordan de havde bygget deres design, forklare hvordan en færdig version skulle se ud og fortælle, hvad de havde haft af udfordringer og måske gerne ville have hjælp til. Som feedbackkriterier brugte vi elevernes egne vurderinger fra dag 2 af, hvad et godt design var. Dette for at sætte fokus på, at det er vi brugere - altså mennesker - der i sidste ende bestemmer, om ens design er vellykket.

I vores eksperiment ønskede vi, at eleverne skulle få en første fornemmelse for interaktion med brugere. Vores intention var, at eleverne skulle opleve, at der, selvom de selv syntes, at deres design var færdigt, stadig var ting, der kunne forbedres, efter de havde fået feedback fra andre. Af samme grund rammesatte vi brugerfeedbacken med, at de skulle ændre mindst én ting efterfølgende i enten kode eller fysisk design. Herefter skulle de forberede deres præsentation på maks. seks minutter til senere på dagen ud fra givne kriterier (se undervisningsslides).

Inden præsentationen vendte vi tilbage til programmeringsdelen. Dette var en ændring i forhold til den oprindelige plan, hvor vi havde sat mere tid af til det fysiske design, brugerfeedback og forberedelse af præsentation. Vi havde ganske enkelt mere tid end tiltænkt, og vi vurderede, at der var behov for at tale mere eksplicit om, hvad de enkelte dele af deres program gjorde. Grupperne præsenterede derfor skiftevis deres koder for hinanden, mens vi stillede spørgsmål. Vi drøftede også i plenum, hvordan man kunne forbedre koderne, eksempelvis ved at bruge mere effektive metoder.

Som sidste del af eksperimentet skulle eleverne præsentere deres design for en parallelklasse samt to af deres lærere. Her fremlagde de også de dele, de havde haft problemer med, men som de nu havde løst gennem afprøvning og feedback. For eksempel fortalte en gruppe, at de fandt ud af, at gult og hvidt lys var for tæt på hinanden, dvs. for svære at skelne fra hinanden, så de brugte en anden farve i stedet. Samme gruppe forklarede, at de til at starte med havde problemer med, at deres fysiske prototype væltede, så de ændrede på designet efter feedback. Også materialer blev drøftet, for eksempel: "Normalt så skal den være lavet af metal og ikke pap og gaffatape og plastikkopper". Præsentationen satte punktum for eksperimentet, som vi derefter evaluerede med eleverne.

\section{Resultater: muligheder og udfordringer}

I dette afsnit diskuterer vi fagdidaktiske muligheder og udfordringer set fra vores perspektiv - men også fra elevernes. Med udgangspunkt i en række spørgsmålı evaluerede vi eksperimentet grundigt med eleverne $_{11}$, da vi anså det som en væsentlig del af et kvalitativt designeksperiment som dette - og af undervisning i det hele taget - at kommunikere om udvikling med dem, det hele handler om.

Vores analyse af resultater tager udgangspunkt i vores to primære hypoteser, dvs. en forventet modstand mod at de ville lave om på deres produkter efter brugerfeedback, samt et snævert syn på datalogi som det samme som programmering. I vores analyse af eksperimentet har vi dog også identificeret andre

10 Se undervisningsslides, slide nr. 63.

11 Talesproget i nogle af citaterne er let redigeret af hensyn til læsevenligheden, dog uden at ændre betydningen af nogle af elevernes udsagn. 
henholdsvis muligheder og udfordringer, herunder ændrede opfattelser af og nye muligheder for succes med datalogi, succes med kreative afbræk og vekslende arbejdsmåder, positiv betydning af autenticitet for elevernes forståelse og ønsket om flere frihedsgrader.

\section{Modstand mod ændringer}

Efter første iteration af designprocessen, hvor grupperne havde givet hinanden feedback, gav vi som beskrevet eleverne det benspænd, at de skulle lave mindst én ændring i deres design. Det var forskelligt, hvordan det blev modtaget af forskellige grupper af elever. Nogle gik straks i gang med at gøre deres produkt mere stabilt i designet, eller ændrede i programmeringen, men nogle grupper mente som forventet, at deres produkt var færdigt og syntes således ikke, det var nødvendigt at inkorporere den feedback, de havde fået. Det kom blandt andet til udtryk ved, at nogle elever umotiveret forlod klassen, fordi de mente, de var færdige.

Denne type af modstand mod at lave visse ændringer viste sig også på et andet punkt, eksempelvis da en gruppe i deres fremlæggelse viste tegn på ikke at have forstået, hvad deres LED-strip egentlig viste. Selvsamme gruppe havde fået ekstra hjælp til design og programmering af LED'erne, men de var mere interesserede i at få LED'erne til at lyse på en bestemt måde, som de syntes så pænt ud, end på at LED'erne repræsenterede information om $\mathrm{CO}_{2}$-udledning. Eksempelvis spurgte gruppen gentagne gange om hjælp til at få LED'erne til at lyse grønt, selvom vi snakkede med dem om, at de kun ville lyse grønt, når $\mathrm{CO}_{2}$-udledningen i Danmark var lav. De ville med andre ord have LED'erne til altid at lyse i en bestemt konfiguration, uagtet at der løbende skete ændringer i $\mathrm{CO}_{2}$-udledningsdata.

Der var altså både modstand mod at lave ændringer og et ønske om, at det var vigtigere, at et produkt så pænt ud, end at det rent faktisk reagerede korrekt på inddata.

\section{Elevernes syn på datalogi}

Vores mundtlige evaluering med eleverne viste, at de stadig efter forløbet havde et snævert syn på, hvad en programmør lavede, når vi spurgte ind til det specifikke begreb. Eksempelvis svarede en elev, at en programmør er en person, der: "skriver en hel masse koder og tester dem og ser og sådan noget ... og laver ikke rigtig meget andet i sin arbejdstid end at sidde og skrive koder", og en anden svarede, at det er: "én, der ved en hel masse om forskellige mekanismer til computeren i hvert fald, for jeg tror, de arbejder meget ved computer." Dette syn blev bredere, når vi diskuterede begrebet yderligere samt spurgte til, hvad en datalog og en designer laver.

En elev forklarede, at en designer: "stiller sig selv spørgsmål: 'Er det godt nok?', Har den alle de her krav?' (..) Og hvis ikke, så laver han den helt om. (...) Man bliver ved med at prøve.” En anden spurgte: "Var det ikke det dér med de dér tre, hvor han bygger ... han designer en prototype (...) og så går han til design, prototype, design, prototype, afprøve ... og så går han tilbage efterfølgende?” Om en datalogs arbejde sagde eleverne, at det, er: "en meget klog og tålmodig person". En anden mente: "en meget præcis person, for man skal taste de dér koder helt præcist", hvortil en tredje svarede: "Ja, præcis og tålmodig (...) og én der kan overskue mange ting." En fjerde påpegede, at en datalog er: "én, som kan tænke meget bredt (...)", og en femte påpegede, at det er: "én der har et godt overblik. For han skal altid lige kunne gennemskue, hvis der er en fejl." Om fejl sagde en anden, at: "Altså ét bogstav, som jeg kom til at skrive lille, det skulle være stort. Og det er sådan noget, man ikke lægger mærke til så nemt."

Af dette udleder vi, at enkelte har oplevet, at dataloger skal kunne tænke bredt, men at andre har den snævre opfattelse, vi var bekymrede for. Deres måde at svare på kan muligvis hænge sammen med måden, vi stillede spørgsmålet på - som to adskilte arbejdsområder - men vi mener stadig at kunne konkludere, at så kort forløb som vores ikke har været nok til at give eleverne en forståelse af, at dataloger ikke kun skriver koder. At de for eksempel også nogle gange arbejder med design. 


\section{Ændrede opfattelser og nye muligheder for succes}

Hvor det ikke til fulde lykkedes at give eleverne en oplevelse af bredden af datalogi, observerede vi andre ændringer i deres opfattelser. Nogle havde for eksempel regnet med, at det ville have været meget sværere: "Da I begyndte at forklare, hvad det ville være, så tænkte jeg: 'Okay, jeg tror ikke, det kommer til at gå så godt', men så da jeg kom i gang, og rent faktisk sad stille og roligt og lavede noget, og det blev forklaret ordentligt, så syntes jeg, det var sjovt". En anden fortalte: "Jeg synes, det var meget lettere, end jeg havde regnet med. Jeg har jo siddet og set de store firmaer, der bare skriver 100 koder på ti minutter og tænkt: 'Hvis det er det, vi skal ... jeg giver op'."

I samme boldgade var der en af eleverne, der påtænker en karriere inden for it, der vurderede, at: "Jeg synes, det var rigtig, rigtig sjovt det her. Det var selvfølgelig også noget nyt noget, og det er noget, jeg interesserer mig for, så (...) og jeg kommer til at bruge det senere, når jeg skal arbejde med it også. Jeg er også blevet rimelig overrasket, for jeg havde regnet med, det var virkelig, virkelig svært og tog virkelig, virkelig lang tid, men det går meget hurtigt, og det er meget lettere, end jeg havde regnet med."

Flere af eleverne brugte hankøn om både en designer og en datalog. I forbindelse med samtalen om datalogers arbejde, spurgte vi ind til dette og diskuterede, om det altid var en "han". En elev svarede: "Eller hun. Det er bare en person." Vi spurgte, om de tænkte, dataloger er noget, mænd er, hvortil eleven svarede ja. En anden svarede: "Jeg tænker, det er noget, alle, både mænd og kvinder, kan gøre, for min mor har også arbejdet med det", og en tredje svarede: "Det kan alle. Equality." En fjerde sagde: "Vi har jo alle sammen gjort det herinde", mens en femte beskrev, at hans syn havde ændret sig, for i begyndelsen tænkte han kun mænd. Men nu: "For eksempel, vi har mødt Maja, (...) og hun arbejder også med sådan noget. Så jeg går ud fra, at der er ligeså mange kvinder, som der er mænd.” Disse udsagn peger mod vigtigheden af, at vi italesætter og synliggør, at datalogi ikke er et kønsbestemt fagområde.

En elev var også overrasket over, hvad de kunne: "Jeg er overrasket over, hvor gode mig og Kasper er til design. (...) Jeg har altid været dårlig til at bygge ting, og så har jeg bygget sådan én her. Jeg er glad.” Elevens oplevelse er ikke bare et udtryk for en ændret opfattelse, men viser også at designelementet kan give nye muligheder for succes. At koblingen mellem udvikling af kompetencer inden for datalogisk tænkning og designtænkning potentielt kan give elever nye muligheder for succesoplevelser.

\section{Kreative afbræk og vekslende arbejdsmåder}

Et andet potentiale ved koblingen mellem datalogisk tænkning og designtænkning er muligheden for at give eleverne en mere alsidig undervisning, hvor der kan veksles mellem flere domæner, og undervisningen således ikke bliver ensformig. Det kom blandt andet til udtryk ved, at nogle elever fik fornyet ny energi, når de skiftede til det kreative. En elev sagde for eksempel: "Jeg synes, det var lidt kedeligt (...), og jeg tog det ikke så godt, men jeg var rigtig glad for det, da vi var kreative, og da vi skulle bygge den dér. Det var sjovt nok.”

Modsat svarere en elev: "Jeg synes, det har været rigtig sjovt (...) jeg har lært en masse, og der var intet af det, jeg synes, der var kedeligt, men det sjoveste, synes jeg, var, da vi skulle bygge og komme med vores ideer."

Også brugen af parprogrammering, dvs. vekslen mellem forskellige roller, gav ny energi. En elev udtalte: ”Det sjoveste det var nok det dér med navigatør og kører. (...) Det synes jeg var meget sjovt, fordi så skulle man sidde og forsøge og omformulere det, så den anden person forstod det."

Vi havde udarbejdet arbejdsark \#1, der introducerede programmering af LED-strips, sådan, at eleverne først skulle arbejde med LED-strips uden brug af løkker, som kunne gøre forkorte koden, så eleverne ikke skulle skrive den samme kode igen og igen. Det havde vi gjort for, at eleverne ikke skulle lære for 
mange koncepter samtidig, og for at løkker blev introduceret på et tidspunkt, hvor eleverne ville se det som noget smart, der gjorde deres arbejde nemmere. Hvis de havde lært om løkker fra starten - og altså ikke oplevet, hvordan det ville være at mangle dem - formodede vi, at de ikke ville opdage det smarte ved dem.

Da vi spurgte ind til denne del af undervisningen, var elevernes vurderinger blandede. Eksempelvis sagde en elev, at: "Jeg synes, det var kedeligt, men der var også noget sjovt ved det. For eksempel vidste jeg jo ikke, at man kunne lave det dér programmering (...) med LED-lys ". Vi spurgte ind til, hvad der var kedeligt, og eleven uddybede med: "At man skulle sidde og skrive det [linjer af koder, der skulle gentages], selvom der var en hurtigere måde." Vi havde en dialog om, at det med vilje var "lavet kedeligt" med gentagelse af kodelinjer, så de senere kunne opdage, at der var en smartere måde.

Som et første eksperiment finder vi med udgangspunkt i elevernes og egen evaluering undervisningen vellykket - men kulturelle ændringer og yderligere erfaring med arbejdsmåderne er påkrævet, hvis eleverne skal udvikle sig videre til mere selvstændigt reflekterende og innovative datalogiske designere.

\section{Konklusion og perspektiver}

Dette eksperiment havde til formål at undersøge undervisning i datalogisk tænkning og designtænkning i dansk almendannede grundskole gennem udvikling af et datalogisk design til autentisk problemløsning og derved udlede fagdidaktiske henholdsvis muligheder og udfordringer i en sådan undervisning. Specifikt udformede vi undervisningen som et designeksperiment, der tog udgangspunkt i en problemstilling inden for det naturfaglige område, hvor eleverne skulle udvikle et digitalt design, der kunne hjælpe mennesker med at udlede mindre $\mathrm{CO}_{2}$ gennem deres elektricitetsforbrug.

I eksperimentet støttede vi os særligt til to modeller, som vi anvendte didaktisk både før og under eksperimentet. Naurs model (Figur 1) om forholdet mellem problemer, værktøjer og mennesker brugte vi til at tydeliggøre målet om at udvikle en løsning på et problem i verden for mennesker med brug af værktøjer. I den henseende er en vigtig pointe, at det i virkelighedens verden ikke hjælper noget at have programmeret fejlfrie LED'er, hvis mennesker ikke kan se anvendeligheden af ens design. Hvis menneskelige brugere eksempelvis ikke kan se forskel på LED'ernes farver, som en gruppe opdagede, er det lige meget, at de er programmeret korrekt. Der må være en bevidst relation mellem både problem, mennesker og værktøjer, og vi bør huske alle tre elementer, når vi arbejder med området i skolen. Designtænkningsmodellen (Figur 3) anvendte vi til at planlægge de forskellige trin i eksperimentet samt som et holdepunkt undervejs til at holde fokus på, hvor vi var, hvad vi havde gjort, og hvad næste skridt var. Vi kombinerede således datalogisk tænkning og designtænkning med det begreb, Denning kalder computational design, og som vi oversætter til datalogisk design (Figur 2).

Vores analyse tog udgangspunkt i vores to primære hypoteser: modstand fra eleverne mod at ville lave om på deres produkter efter brugerfeedback, samt et syn på datalogi som det samme som programmering. Disse hypoteser blev delvist bekræftet. I forhold til modstand mod ændringer, betød den styrede form, vi havde valgt for undervisningen dog, at også elever med modstand mod det blev "tvunget" til at ændre mindst én ting i deres design, men på sigt er det målet, at eleverne selv kan se mulighederne i brugerfeedback og justeringer. I forhold til elevernes syn på datalogi forstod enkelte elever, at dataloger skal kunne tænke bredt, men andre havde efter endt forløb en snæver opfattelse af dataloger som nogle, der (kun) skriver koder.

I vores analyse af eksperimentet identificerede vi også andre henholdsvis muligheder og udfordringer, herunder ændrede opfattelser af og nye muligheder for succes med datalogi, succes med kreative afbræk og vekslende arbejdsmåder, positiv betydning af autenticitet for elevernes forståelse og ønsket om flere frihedsgrader. Sidstnævnte kom af, at vi havde valgt, hvilket problem eleverne skulle arbejde med som modellering af, hvordan en datalogisk designer kan arbejde, men gennem bevidst arbejde med kultur 
og projektorienteret arbejdsmåde vil man med tiden kunne give eleverne flere frihedsgrader. At give eleverne friere tøjler i arbejdet ville dog kræve en høj grad selvstændighed og kulturændringer, som vi ville have brug for mere tid i klassen til at arbejde med.

I den forbindelse er kontekst og skolekultur af betydning i forhold til de måder, eleverne er vant til at arbejde på. Det var en udfordring, at vi ikke kendte eleverne på forhånd, ligesom vi ikke var bekendte med klassens konventioner, kulturelle koder samt måder at arbejde på. Større kulturændringerne sker ikke fra den ene til den anden dag - de kræver tid og øvelse, og det ville være urealistisk at "opdrage" meget på eleverne eller forlange, de kunne ændre vaner på et tredages eksperiment. Derfor valgte vi bevidst ikke at gå i dybden med og bruge tiden på dette, men at fokusere på det faglige indhold, hvilket betød, at vi så vidt muligt fulgte klassens konventioner og lod klassens normale lærere, der var til stede $\mathrm{i}$ en overvejende del af undervisningen, holde styr på eksempelvis protokol, interne sociale problematikker og elever, der forlod klassen midt i timen. Konkret var nogle elever mere til stede både fysisk og mentalt i undervisningen end andre, og vi oplevede en række sociale og faglige udfordringer, som vi ikke havde mulighed for at arbejde med på den korte tid.

Foruden at bidrage til teknologiforståelsesdidaktik er hensigten med dette eksperiment også at inspirere til videre fagdidaktisk forskning inden for teknologiforståelse. Ved at gøre forløbets undervisningsplan, slides og arbejdsark frit tilgængelige, håber vi, flere får lyst til at afprøve eller videreudvikle på teori og praksis. Selvom vores undervisningsdesign ikke tager udgangspunkt i læseplanen for forsøgsfagligheden teknologiforståelse, lægger det sig i høj grad ind i flere af læseplanens kompetenceområder og passer ind i det brede almendannende perspektiv, vi ser i forsøgsfagets Fælles Mål samt i traditionerne for og det overordnede formål med dansk skole.

\section{Referencer}

Barab, S. \& Squire, K. (2004). Design-Based Research: Putting a Stake in the Ground. The Journal of the Learning Sciences, 13(1): 1-14. https://doi.org/10.1207/s15327809jls1301_1

Caeli, E. N. (forthcoming). Ph.d.-afhandling.

Caeli, E. N. \& Bundsgaard, J. (2020). Teknologikritik i skolen - et demokratisk perspektiv på teknologiforståelse. I: Haas, C. og Matthiesen, C. (red.). Fagdidaktik og demokrati. Samfundslitteratur.

Cross, N. (2011). Design Thinking: Understanding how designers think and work. Bloomsbury.

Denning, P. J. (2017). Computational Design. ACM Ubiquity. Volume 2017, August: 1-9. https://dl.acm.org/doi/10.1145/3132087

EMU (2019). Formålet for forsøgsfaget teknologiforståelse. https://www.emu.dk/grundskole/forsogsfagteknologiforstaelse/formal. Undervisningsministeriet.

Hattie, J. \& Timperley, H. (2007). The Power of Feedback. Review of Educational Research, 77(1). https://doi.org/10.3102/003465430298487

Naur, P. (1965). The Place of Programming in a World of Problems, Tools, and People. Proc. IFIP Congress 65: 165-199.

Naur, P. (1970). Planer og ideer for datalogisk institut ved Københavns Universitet. Studentlitteratur.

Katapult/TEACH (2013). Værktøjskassen: Model for designtænkning. Projektet Next Generation. Københavns Universitet. https://innovation.sites.ku.dk/model/design-thinking/

Klafki, W. (2001). Dannelsesteori og didaktik - nye studier. Klim.

Smith, R. C.; Iversen, O. S.; \& Veerasawmy, R. (2016). Impediments for Digital Fabrication in Education: A study of teachers' role in digital fabrication. International Journal of Digital Literacy and Digital Competence, Vol. 7(4). https://doi.org/10.4018/IJDLDC.2016010103

Tabel, O.; Jensen, J.; Dybdal, M.; \& Bjørn, P. (2017). Coding as a social and tangible activity. Interactions, 24(6): 70-73. https://doi.org/10.1145/3137099 


\section{Bilag 1. Undervisningsplan}

Bilaget viser den overordnede undervisningsplan. Undervisningsslides og arbejdsark er frit tilgængelige og kan hentes på: https://silo1.sciencedata.dk/shared/designeksperiment

\section{Dag 1}

\begin{tabular}{|c|c|c|c|}
\hline Formål & $\begin{array}{l}\text { Introduktion til forløb og } \\
\text { fagligt indhold } \\
\text { Udvikling af forståelse for } \\
\text { problematikken }\end{array}$ & $\begin{array}{l}\text { Udvikling af forståelse for } \\
\text { data - specifikt fra } \\
\text { electricitymap.org } \\
\text { Praktiske forberedelser }\end{array}$ & $\begin{array}{l}\text { Udvikling af } \\
\text { programmeringskompe- } \\
\text { tencer }\end{array}$ \\
\hline \multirow[t]{2}{*}{ Indhold } & $8.00-9.50$ & 10.10-12.00 & $\begin{array}{l}\text { 12.30-14.00 / 14.15- } \\
15.00\end{array}$ \\
\hline & $\begin{array}{l}\text { 20 min: Introduktion til } \\
\text { os, til eksperiment og } \\
\text { overordnet plan - vis } \\
\text { designmodel } \\
\text { Forstå problemet } \\
\text { 2o min: Flerstemmig } \\
\text { dialog: Iscenesætte } \\
\text { problematik/aktivere } \\
\text { forforståelse for } \\
\text { klimaproblematikken } \\
\text { Video } \\
\text { 2o min: Diskutere, hvad } \\
\text { man kan gøre ved } \\
\text { klimaforandringerne } \\
\text { Forstå data/afgræens } \\
\text { 20 min: Strømforbrug vs. } \\
\text { produktion i Danmark } \\
\mathbf{1 5} \text { min: } \\
\text { Computeropsætning, } \\
\text { login, wifi-tilslutning } \\
\mathbf{1 5} \text { min: Udforsk } \\
\text { electricitymap.org } \\
\mathbf{1 0} \text { min: Samle op og lede } \\
\text { op til den løsning, vi skal } \\
\text { arbejde med }\end{array}$ & $\begin{array}{l}\text { Ideer } \\
\mathbf{1 5} \text { min: Design tilpasset } \\
\text { problemet } \\
\text { Hvorfor vil det ikke du } \\
\text { med en app? } \\
\text { Sammenlign med andre } \\
\text { dataindikatorer vi har i } \\
\text { hjemmet } \\
\text { Prototype } \\
\text { 10 min: Introduktion til } \\
\text { parprogrammering: } \\
\text { Fordele/ulemper? } \\
\text { 10 min: Introduktion til } \\
\text { microcontrollere, LED- } \\
\text { strips og Mu-editoren } \\
\text { 1²/2 time: Arbejdsark \#1 } \\
\text { Parprogrammering i } \\
\text { praksis - tag tid, så de } \\
\text { skifter roller } \\
\text { Mu-editor, tilslutning af } \\
\text { microcontroller, tilslut } \\
\text { LED-strip, ændre farver, } \\
\text { lav et mønster } \\
\text { Introduktion til variabler } \\
\text { Ændre deres kode til at } \\
\text { bruge variabler }\end{array}$ & $\begin{array}{l}\text { Prototype } \\
2 \text { 1/4 time: Arbejdsark \#2 } \\
\text { Introduktion til at logge } \\
\text { på Wifi og hente data fra } \\
\text { ElectricityMap } \\
\text { Tilføj kode til at hente } \\
\mathrm{CO}_{2} \text {-forureningsniveau fra } \\
\text { ElectricityMap } \\
\text { Introduktion til if- } \\
\text { sætninger } \\
\text { Ændre kode til at skifte } \\
\text { farver baseret på } \mathrm{CO}_{2-} \\
\text { niveau }\end{array}$ \\
\hline Materialer & $\begin{array}{l}\text { Computer, adgang til } \\
\text { electricitymap.org, } 4 \mathrm{G} \\
\text { wifihotspot }\end{array}$ & $\begin{array}{l}\text { Computer, } \\
\text { microcontroller, LED- } \\
\text { strip, } 4 \mathrm{G} \text { wifihotspot, } \\
\text { arbejdsark }\end{array}$ & $\begin{array}{l}\text { Computer, } \\
\text { microcontroller, LED- } \\
\text { strip, 4G wifihotspot, } \\
\text { arbejdsark }\end{array}$ \\
\hline
\end{tabular}




\section{Dag 2}

\begin{tabular}{|c|c|c|c|}
\hline Mål & $\begin{array}{l}\text { Udvikling af } \\
\text { designkompetencer }\end{array}$ & $\begin{array}{l}\text { Udvikling af } \\
\text { programmeringskompe- } \\
\text { tencer }\end{array}$ & $\begin{array}{l}\text { Udvikling af } \\
\text { designkompetencer }\end{array}$ \\
\hline \multirow[t]{2}{*}{ Indhold } & 8.00-9.50 & 10.10-12.00 & $12.30-14.00$ \\
\hline & $\begin{array}{l}\mathbf{1 0} \text { min: Tilbage til } \\
\text { problemstillingen: Hvor } \\
\text { er vi i designprocessen? } \\
\mathbf{5} \text { min: Introduktion til } \\
\text { designdel } \\
\text { Ideer } \\
\text { 2o min: Flerstemmig } \\
\text { dialog om design: Hvad er } \\
\text { et godt/dårligt design? } \\
\text { Hvad skal man tænke på, } \\
\text { når man interagerer med } \\
\text { brugere? Hvad er vigtigt i } \\
\text { et design? Skriv } \\
\text { punkterne op } \\
\mathbf{2 5} \text { min: Inspiration fra } \\
\text { brugere. Hvad synes } \\
\text { andre er et godt design? } \\
\text { Video } \\
\mathbf{2 0} \text { min: Introduktion til } \\
\text { prototype: Skitse på papir, } \\
\text { før de bygger. Bygge i pap, } \\
\text { med lim osv. Overveje } \\
\text { rigtig version (farver, } \\
\text { materialer etc.) } \\
\text { 3o min: Idéudvikling og } \\
\text { begynde at bygge } \\
\text { prototype }\end{array}$ & $\begin{array}{l}\text { Ideer og Prototype } \\
\text { Eget tempo } \\
\text { Fortsat idéudvikling og } \\
\text { konstruktion af prototype } \\
\text { Løbende sættes de til at gå } \\
\text { videre med arbejdsark \#3, } \\
\text { \#4 og \#5 } \\
\text { Individuel vejledning } \\
\text { afhængig af niveau og } \\
\text { hastighed }\end{array}$ & $\begin{array}{l}\text { Prototype } \\
2 \text { timer: Færdiggørelse af } \\
\text { prototype } \\
15 \text { min: Afprøvning af } \\
\text { egen prototype }\end{array}$ \\
\hline Materialer & $\begin{array}{l}\text { Computer, } \\
\text { microcontroller, LED- } \\
\text { strip, } 4 \mathrm{G} \text { wifihotspot }\end{array}$ & $\begin{array}{l}\text { Byggematerialer til } \\
\text { prototyper (pap, } \\
\text { limpistoler, flamingo, } \\
\text { tuscher, tape, } \\
\text { hæfteklammer, sakse), } \\
\text { computer, } \\
\text { microcontroller, LED- } \\
\text { strip, 4G wifihotspot }\end{array}$ & $\begin{array}{l}\text { Byggematerialer til } \\
\text { prototyper (pap, } \\
\text { limpistoler, flamingo, } \\
\text { tuscher, tape, } \\
\text { hæfteklammer, sakse), } \\
\text { computer, } \\
\text { microcontroller, LED- } \\
\text { strip, 4G wifihotspot }\end{array}$ \\
\hline
\end{tabular}




\section{Dag 3}

\begin{tabular}{|c|c|c|c|}
\hline Mål & $\begin{array}{l}\text { Udvikling af } \\
\text { designkompetencer } \\
\text { Udvikling af } \\
\text { feedbackkompetencer }\end{array}$ & $\begin{array}{l}\text { Udvikling af } \\
\text { designkompetencer } \\
\text { Udvikling af } \\
\text { feedbackkompetencer }\end{array}$ & $\begin{array}{l}\text { Udvikling af } \\
\text { formidlingskompetencer } \\
\text { Evaluering }\end{array}$ \\
\hline \multirow[t]{2}{*}{ Indhold } & $8.00-9.50$ & $10.10-12.00$ & $12.30-14.00$ \\
\hline & $\begin{array}{l}\mathbf{1 0} \text { min: Opsamling på } \\
\text { dag } 1 \text { og } 2 \text { vha. } \\
\text { designmodellen } \\
\text { Afprøvning } \\
\mathbf{1 5} \text { min: Introduktion til } \\
\text { feedback: to par sammen. } \\
\text { Forklare design, } \\
\text { funktioner og udfordringer } \\
\text { til hinanden } \\
\text { 2o min: Afprøv } \\
\text { hinandens prototype + giv } \\
\text { feedback i forhold til } \\
\text { kriterier for et godt design } \\
\text { fra dag } 2 \\
\\
\text { Prototype } \\
\text { 3o min: Revidering af } \\
\text { design/prototype inden } \\
\text { præsentation: mindst én } \\
\text { ting skal ændres i enten } \\
\text { kode eller design }\end{array}$ & $\begin{array}{l}\text { Afprøvning } \\
\text { 1²/2 time: Grupperne } \\
\text { præsenterer og forklarer } \\
\text { deres koder i plenum } \\
\mathbf{1 0} \text { min: Introduktion til } \\
\text { præsentation, herunder } \\
\text { rammer for indhold og tid } \\
\text { per gruppe } \\
\text { 40 min: Forberede og øve } \\
\text { præsentation }\end{array}$ & $\begin{array}{l}\text { Afprøvning } \\
\text { 11/2 time: Præsentation af } \\
\text { prototyper for hinanden, } \\
\text { parallelklassen samt } \\
\text { lærere } \\
\mathbf{4 5} \text { min: Flerstemmig } \\
\text { evaluering af projektet, fx: } \\
\text { Hvad de har lært, som de } \\
\text { ikke vidste før? Hvad } \\
\text { fungerede godt? Hvad } \\
\text { fungerede ikke så godt? } \\
\text { Hvad har de lært om data? } \\
\text { Hvad har de lært om } \\
\text { design? Hvad har de lært } \\
\text { om programmering? Hvad } \\
\text { overraskede dem? }\end{array}$ \\
\hline Materialer & $\begin{array}{l}\text { Computer, } \\
\text { microcontroller, LED- } \\
\text { strip, } 4 \mathrm{G} \text { wifihotspot, }\end{array}$ & $\begin{array}{l}\text { Computer, } \\
\text { microcontroller, LED- } \\
\text { strip, 4G wifihotspot }\end{array}$ & $\begin{array}{l}\text { Computer, } \\
\text { microcontroller, LED- } \\
\text { strip, } 4 \mathrm{G} \text { wifihotspot }\end{array}$ \\
\hline
\end{tabular}




\section{Forfattere}

\section{Elisa Nadire Caeli}

Ph.d.-stipendiat

Danmarks institut for Pædagogik og Uddannelse (DPU), Aarhus

Universitet samt Institut for Læreruddannelse, Københavns

Professionshøjskole

Forsker i elevers udvikling af datalogisk tænkning og teknologiforståelse i grundskolen

\section{Martin Dybdal}

Ph.d., specialkonsulent

Datalogisk Institut, Københavns Universitet

Forsker i og arbejder med datalogididaktik og formidling fra grundskole- til universitetsniveau
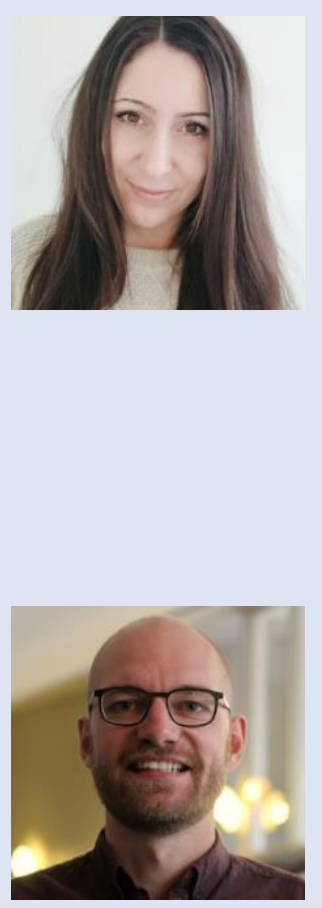